\title{
Canine infection with Dirofilaria immitis, Borrelia burgdorferi, Anaplasma spp., and Ehrlichia spp. in the United States, 2013- 2019
}

Susan Little ${ }^{1 *}$, Jennifer Braff², Joshua Place ${ }^{1}$, Jesse Buch², Bhagya Galkissa Dewage ${ }^{1}$, Andrew Knupp ${ }^{2}$ and Melissa Beall ${ }^{2}$

\begin{abstract}
Background: Dogs in the US are commonly infected with vector-borne pathogens, including heartworm and tick-borne disease agents. The geographic distribution of both arthropod vectors and the pathogens they transmit continues to expand.

Methods: To describe the current geographic distribution and prevalence of antigen of Dirofilaria immitis and antibody to Borrelia burgdorferi, Ehrlichia spp., and Anaplasma spp. in dogs, we summarized over 144 million test results from 2013 to 2019, inclusive, by county, state, and region. Canine seroprevalence by state was compared to population-adjusted human reports of tick-borne diseases.

Results: Results varied regionally, with D. immitis antigen and Ehrlichia spp. antibodies more frequently detected in the Southeast (2.6\% and 5.2\%, respectively) and antibody to B. burgdorferi and Anaplasma spp. most common in the Northeast ( $12.1 \%$ and $7.3 \%$, respectively). Overall, percent positive test results to $D$. immitis decreased in the Southeast by 33.3\% when compared to earlier summaries using the same strategy (from 3.9 to $2.6 \%$ ). Geographic expansion of areas where dogs commonly test positive for Ehrlichia spp. was evident, likely because of a change in the test made in 2012 to allow detection of antibodies to E. ewingii concomitant with expansion of vector tick populations. Percent positive test results to Ehrlichia spp. increased in every region; this shift was particularly pronounced in the Southeast, where percent positive test results increased fourfold (from 1.3 to 5.2\%). Continued geographic expansion of B. burgdorferi and A. phagocytophilum was apparent in the Northeast, Midwest, and Upper South, although canine seroprevalence of antibody to $B$. burgdorferi was much lower than prior surveys in many Lyme-endemic areas. Annual reports of human cases of Lyme disease, ehrlichiosis, and anaplasmosis were associated with percent positive canine results by state for the three tick-borne disease agents $\left(R^{2}=0.812,0.521\right.$, and 0.546 , respectively). Within endemic areas, percent positive test results for all three tick-borne agents demonstrated evidence of geographic expansion.
\end{abstract}

*Correspondence: susan.little@okstate.edu

${ }^{1}$ Department of Veterinary Pathobiology, College of Veterinary Medicine, Oklahoma State University, Stillwater, OK, USA

Full list of author information is available at the end of the article

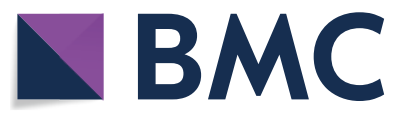

(c) The Author(s) 2021. This article is licensed under a Creative Commons Attribution 4.0 International License, which permits use, sharing, adaptation, distribution and reproduction in any medium or format, as long as you give appropriate credit to the original author(s) and the source, provide a link to the Creative Commons licence, and indicate if changes were made. The images or other third party material in this article are included in the article's Creative Commons licence, unless indicated otherwise in a credit line to the material. If material is not included in the article's Creative Commons licence and your intended use is not permitted by statutory regulation or exceeds the permitted use, you will need to obtain permission directly from the copyright holder. To view a copy of this licence, visit http://creativeco mmons.org/licenses/by/4.0/. The Creative Commons Public Domain Dedication waiver (http://creativecommons.org/publicdomain/ zero/1.0/) applies to the data made available in this article, unless otherwise stated in a credit line to the data. 
Conclusions: Large scale analysis of results from screening dogs in practice for evidence of vector-borne infections, including those with zoonotic importance, continues to be a valuable strategy for understanding geographic trends in infection risk over time.

Keywords: 4DxPlus, Anaplasma, Antibody, Antigen, Borrelia burgdorferi, Canine, Dirofilaria immitis, Ehrlichia

\section{Background}

National summaries of canine vector-borne disease seroprevalence generated from testing individual dogs in practice aid understanding of pathogen distribution and provide insights into geographic and temporal changes $[1,2]$. To facilitate early diagnosis, treatment, and prevention, advisory boards recommend that all dogs receiving veterinary care be evaluated annually for vector-borne infections [3]. Accordingly, each year in the US, millions of dogs are tested for antigen of heartworm (Dirofilaria immitis) and antibody to tick-borne disease agents, most commonly Borrelia burgdorferi, agent of Lyme borreliosis; Anaplasma spp., which cause anaplasmosis in people and animals; and Ehrlichia spp., causative agents of human and canine ehrlichiosis [1, $2,4,5]$. In addition to benefiting canine patient health, analysis of the aggregated results captured using the same test method over many years can serve as a bellwether to identify areas where infection risk may be changing [6-8].

Despite the widespread availability of preventives, ticks are common on dogs across the USA, and evidence suggests the prevalence of heartworm infection and of antibodies to tick-borne disease agents is increasing in some regions [9-12]. These increases likely result from a combination of factors including increased vector populations, resulting in more intense transmission, geographic spread of natural maintenance cycles for infection, and translocation of infected dogs [11-16]. Canine serologic evidence of past or current tick-borne infection also correlates with human case reports on a county- and statewide basis $[2,6,10,17]$, and the number of human cases is similarly increasing [18]. In the present article, we update our earlier publications by reporting the percent positive test results of dogs evaluated by veterinarians in the US from 2013 to 2019, documenting continued changes in both distribution of these infections and overall infection risk.

\section{Materials and methods Source of data}

Results for the present analysis and summary (20132019) were generated using USDA-licensed test kits (IDEXX Laboratories, Inc.) and included: SNAP ${ }^{\circledR} 4 \mathrm{Dx}^{\circledR}$ Plus Test kit, an in-clinic enzyme-linked immunosorbent assay (ELISA) for detection of $D$. immitis antigen and canine antibodies to B. burgdorferi, Ehrlichia spp. (E. canis, E. ewingii), and Anaplasma spp. (A. phagocytophilum and $A$. platys); SNAP ${ }^{\circledR}$ HW RT Test kit, an in-clinic ELISA for the detection of $D$. immitis antigen in canine serum, plasma, or whole blood. In addition, results generated from microtiter plate ELISA tests for the detection of D. immitis antigen (e.g., PetChek ${ }^{\circledR}$ Heartworm PF Test) and canine antibodies to B. burgdorferi, Ehrlichia spp. (E. canis, E. ewingii), and Anaplasma spp. (A. phagocytophilum and A. platys) in canine serum or plasma at a reference laboratory were included. The performance of each test and associated diagnostic reagents has been reported previously $[1,2,19]$.

Testing results were collated from two sources: (i) directly from veterinary practices testing patients inclinic (SNAP ${ }^{\circledR}$ HW RT Test and SNAP ${ }^{\circledR} 4 \mathrm{Dx}^{\circledR}$ Plus Test) and (ii) through the IDEXX Reference Laboratories network (PetChek ${ }^{\circledR}$ Heartworm PF and Lab 4Dx ${ }^{\circledR}$ Plus Test). Results from veterinary practices were recorded in IDEXX VetLab ${ }^{\circledR}$ Instrumentation and Software and either automatically recorded by the IDEXX SnapShot $\mathrm{Dx}^{\circledR}$ Instrument or SNAP Pro ${ }^{\circledR}$ Analyzer or manually entered by clinic staff. To ensure data privacy, results were collected without owner information or canine patient identification and thus repeat testing events or translocated dogs (i.e. dogs with a travel history to another region) cannot be identified or omitted.

\section{Data analysis}

State and county of the veterinary hospital providing the test result or submitting the sample to the laboratory were used to assign results to region as previously described [1, 2, 20], with four primary regional groups (Midwest, Northeast, Southeast, and West) used to compare results to previous publications. Percent positive results were calculated by dividing the number of tests reported as positive for each agent by the total number of testing events recorded in each county, state, or region. For state-wide summary tables and comparison to human disease reports, all results collected from 2013 to 2019 were included. For construction of maps depicting percent positive test results by county, individual counties with fewer than 210 total test results, or fewer than an average of 30 test results per study year, were excluded $[1,2]$ and then maps created with $R$ (version 3.6.1) [21] using the albersusa [22] and tmap [23] packages. 


\section{Statistical analyses}

Reported total human cases in each state of Lyme borreliosis, ehrlichiosis, and anaplasmosis as documented in Centers for Disease Control and Prevention (CDC) Summary of Notifiable Infectious Diseases, 2009 through 2018, inclusive [24], were adjusted to reflect reported cases per 100,000 people using intercensal estimates of average state population data from the United States Census Bureau [25]; the 2019 CDC Summary of Notifiable Infectious Diseases was not available when analysis was performed. State-by-state comparison of population-adjusted human disease reports with canine seroprevalence was performed for each respective agent (B. burgdorferi, Ehrlichia spp., and Anaplasma spp.) using linear regression with significance assigned at $p<0.0001$ and the coefficient of determination $\left(R^{2}\right)$ and $F$ statistic calculated using Excel 2016 (Microsoft, Redmond, WA).

\section{Results}

\section{Summary}

A total of 144,022,232 results were available from dogs tested in 2298 counties and in all 50 states in the US over the 7-year period summarized in the present paper (Tables 1, 2, 3, 4). This represented results from nearly 50 million tests for antigen of $D$. immitis and more than 30 million tests for antibodies to B. burgdorferi, Ehrlichia spp., and Anaplasma spp. Evidence of all four agents was found in dogs from every state considered. Distribution of positive tests and relative percent positive values by county and state are shown in Figs. 1, 2, 3, 4.

\section{Heartworm}

Percent positive test results for $D$. immitis antigen were higher in the Southeast than in the other three regions and were higher in the West and Midwest than in the Northeast (Table 1, Fig. 1). National and regional prevalence of percent positive test results for D. immitis was largely unchanged from our previous reports $[1,2]$ with the exception of the Southeast, where the overall prevalence was lower than in previous reports; this decrease in prevalence was evident in every state in the Southeast except Alabama (Table 1).

\section{Lyme disease}

Percent positive test results for antibody to B. burgdorferi were highest in the Northeast, followed by the Midwest, Southeast, and West (Table 2, Fig. 2). The overall, national prevalence of antibodies to B. burgdorferi was decreased from our previous report (from 7.2 to 5.9\%) and was lower in every region except the Southeast where percent positive test results remained unchanged (Table 2). Prevalence of antibodies to B. burgdorferi for most individual states remained unchanged or decreased; only New York, Iowa, Ohio, and West Virginia were significantly higher than the earlier report (Table 2).

\section{Ehrlichiosis}

Percent positive test results for antibody to Ehrlichia spp. were higher in the Southeast than in the other three regions (Table 3, Fig. 3). National and regional canine seroprevalence for Ehrlichia spp. antibodies was also higher than in previous reports, including twofold higher in the Northeast and as much as threefold higher in the Southeast (Table 3). Prevalence of Ehrlichia spp. antibody was also higher in every state in the Northeast and Southeast, every state in the Midwest except South Dakota, and all states in West except Hawaii, New Mexico, and Washington (Table 3).

\section{Anaplasmosis}

Percent positive test results for antibody to Anaplasma spp. were highest in the Northeast and lowest in the Southeast (Table 4). Overall, seroprevalence of antibodies to Anaplasma spp. decreased nationally (from 4.4 to $3.3 \%$ ) and in every region except the Northeast, where it remained largely unchanged from the previous report (Table 4). By state, percent positive test results for Anaplasma spp. antibodies were lower in states throughout the Southeast, Midwest, and West. In the Northeast, statewide seroprevalence was higher in northern New England (Maine, New Hampshire, Vermont) but lower in several mid-Atlantic states (Connecticut, New Jersey, Rhode Island) (Table 4).

\section{Comparison to human disease reports}

Seroprevalence of B. burgdorferi antibodies in dogs and reported cases of Lyme borreliosis in people by state were positively associated $\left(R^{2}=0.812, F=207.0\right)$. Reported human cases of Lyme borreliosis were lower than expected based on canine seroprevalence in Massachusetts, New York, Virginia, and West Virginia, and higher than expected in Delaware, Maine, New Hampshire, and Vermont. Seroprevalence of Ehrlichia spp. antibodies in dogs and reported cases of ehrlichiosis in people by state were positively associated $\left(R^{2}=0.521, F=52.2\right)$. In some states, reported human cases of ehrlichiosis were lower than expected (Mississippi) based on canine serology. Seroprevalence of Anaplasma spp. antibodies in dogs and reported cases of anaplasmosis in people by state were positively associated $\left(R^{2}=0.546, F=57.6\right)$. In some states, reported human cases of anaplasmosis were lower (Connecticut and Massachusetts) or higher (Vermont) than expected based on canine serology. 
Table 1 Dirofilaria immitis antigen percent positive test results (number positive/number tested) by region and state from dogs tested in the US from 2001 to 2007 [1], 2010 to 2012 [2], and 2013 to 2019

\begin{tabular}{|c|c|c|c|}
\hline State & 2001-2007 [1] & 2010-2012 [2] & 2013-2019 \\
\hline \multicolumn{4}{|l|}{ Northeast } \\
\hline Connecticut & $0.6 \%(236 / 37,650)$ & $0.6 \%(1334 / 234,840)$ & $0.6 \%(6016 / 1,043,798)$ \\
\hline Delaware & $1.6 \%(79 / 4986)$ & $0.9 \%(449 / 51,497)$ & $0.5 \%(905 / 191,348)$ \\
\hline District of Columbia & NR & $0.8 \%(54 / 7065)$ & $0.7 \%(509 / 71,237)$ \\
\hline Maine & $0.6 \%(173 / 27,247)$ & $0.3 \%(699 / 222,119)$ & $0.5 \%(3235 / 639,514)$ \\
\hline Maryland & $0.8 \%(221.28,770)$ & $0.4 \%(1159 / 286,989)$ & $0.4 \%(5169 / 1,215,646)$ \\
\hline Massachusetts & $0.7 \%(1657 / 252,281)$ & $0.5 \%(2570 / 512,302)$ & $0.6 \%(10,680 / 1,863,965)$ \\
\hline New Hampshire & $0.8 \%(168 / 21,056)$ & $0.4 \%(556 / 131,724)$ & $0.6 \%(3268 / 559,139)$ \\
\hline New Jersey & $0.3 \%(384 / 111,245)$ & $0.3 \%(1094 / 356,617)$ & $0.4 \%(5056 / 1,205,338)$ \\
\hline New York & $0.5 \%(780 / 158,926)$ & $0.4 \%(2281 / 620,933)$ & $0.4 \%(10,486 / 2,564,677)$ \\
\hline Pennsylvania & $0.4 \%(191 / 45,815)$ & $0.2 \%(946 / 623,058)$ & $0.4 \%(8818 / 2,334,505)$ \\
\hline Rhode Island & $0.8 \%(123 / 16,199)$ & $0.4 \%(274 / 67,811)$ & $0.7 \%(1097 / 158,349)$ \\
\hline Vermont & $0.7 \%(24 / 3682)$ & $0.4 \%(259 / 60,125)$ & $0.7 \%(1429 / 217,697)$ \\
\hline Region & $0.6 \%(4036 / 707,857)$ & $0.4 \%(11,675 / 3,175,080)$ & $0.5 \%(56,668 / 12,065,213)$ \\
\hline \multicolumn{4}{|l|}{ Midwest } \\
\hline Illinois & $0.9 \%(2915 / 337,434)$ & $0.7 \%(4367 / 614,303)$ & $1.0 \%(23,338 / 2,414,323)$ \\
\hline Indiana & $1.8 \%(428 / 24,290)$ & $1.4 \%(2834 / 207,125)$ & $1.3 \%(13,158 / 980,336)$ \\
\hline lowa & $0.9 \%(164 / 19,097)$ & $0.3 \%(401 / 125,196)$ & $0.4 \%(2466 / 559,015)$ \\
\hline Kansas & $2.7 \%(170 / 6264)$ & $1.0 \%(845 / 80,174)$ & $0.9 \%(3150 / 361,642)$ \\
\hline Michigan & $0.7 \%(2031 / 292,171)$ & $0.8 \%(4129 / 490,541)$ & $0.7 \%(17,232 / 2,361,699)$ \\
\hline Minnesota & $0.4 \%(332 / 80,810)$ & $0.3 \%(693 / 279,699)$ & $0.4 \%(4406 / 1,097,589)$ \\
\hline Missouri & $2.0 \%(457 / 22,673)$ & $1.5 \%(2615 / 173,842)$ & $1.6 \%(14,505 / 898,730)$ \\
\hline Nebraska & $0.8 \%(34 / 4387)$ & $0.7 \%(126 / 17,613)$ & $0.5 \%(801 / 149,756)$ \\
\hline North Dakota & $0.5 \%(25 / 4914)$ & $0.1 \%(16 / 17,100)$ & $0.3 \%(303 / 99,478)$ \\
\hline Ohio & $0.9 \%(1242 / 136,548)$ & $0.6 \%(2717 / 448,847)$ & $0.6 \%(11,706 / 2,107,379)$ \\
\hline South Dakota & $0.1 \%(1 / 962)$ & $0.3 \%(45 / 13,831)$ & $0.4 \%(277 / 79,978)$ \\
\hline Wisconsin & $0.6 \%(616 / 109,745)$ & $0.4 \%(1226 / 349,644)$ & $0.4 \%(5940 / 1,331,056)$ \\
\hline Region & $0.8 \%(8415 / 1,039,295)$ & $0.7 \%(20,014 / 2,817,915)$ & $0.8 \%(97,282 / 12,440,981)$ \\
\hline \multicolumn{4}{|l|}{ Southeast } \\
\hline Alabama & $3.4 \%(622 / 18,388)$ & $3.6 \%(4479 / 125,156)$ & $3.9 \%(24,240 / 629,814)$ \\
\hline Arkansas & $6.8 \%(578 / 8526)$ & $4.6 \%(3402 / 74,386)$ & $4.0 \%(17,793 / 442,206)$ \\
\hline Florida & $1.8 \%(1408 / 80,280)$ & $1.6 \%(11,189 / 696,358)$ & $1.4 \%(41,922 / 3,058,920)$ \\
\hline Georgia & $2.7 \%(1373 / 51,494)$ & $3.2 \%(10,142 / 317,138)$ & $2.6 \%(39,669 / 1,550,488)$ \\
\hline Kentucky & $1.1 \%(227 / 20,092)$ & $1.8 \%(1383 / 75,835)$ & $1.4 \%(7069 / 518,778)$ \\
\hline Louisiana & $6.0 \%(871 / 14,468)$ & $7.4 \%(7133 / 96,223)$ & $7.2 \%(46,444 / 641,766)$ \\
\hline Mississippi & $7.4 \%(183 / 2459)$ & $10.5 \%(2835 / 26,988)$ & $8.1 \%(21,499 / 265,613)$ \\
\hline North Carolina & $3.0 \%(663 / 22,005)$ & $2.4 \%(8772 / 373,078)$ & $2.2 \%(50,390 / 2,326,822)$ \\
\hline Oklahoma & $2.1 \%(254 / 11,913)$ & $3.4 \%(2657 / 79,056)$ & $2.2 \%(9737 / 439,331)$ \\
\hline South Carolina & $5.7 \%(860 / 15,019)$ & $2.9 \%(4640 / 160,252)$ & $2.6 \%(23,949 / 906,389)$ \\
\hline Tennessee & $3.6 \%(498 / 13,787)$ & $3.4 \%(6937 / 204,231)$ & $2.6 \%(23,956 / 936,084)$ \\
\hline Texas & $5.5 \%(12,160 / 220,829)$ & $3.9 \%(34,066 / 872,096)$ & $3.5 \%(140,198 / 3,990,180)$ \\
\hline Virginia & $1.1 \%(331 / 29,766)$ & $1.0 \%(3827 / 384,074)$ & $0.9 \%(17,702 / 2,038,858)$ \\
\hline West Virginia & $0.8 \%(51 / 6131)$ & $0.5 \%(388 / 77,319)$ & $0.4 \%(1205 / 274,360)$ \\
\hline Region & $3.9 \%(20,079 / 515,157)$ & $2.9 \%(101,850 / 3,562,190)$ & $2.6 \%(465,773 / 18,019,609)$ \\
\hline \multicolumn{4}{|l|}{ West } \\
\hline Alaska & NR & $2.3 \%(13 / 566)$ & $1.4 \%(54 / 3,768)$ \\
\hline Arizona & $1.2 \%(620 / 53,809)$ & $0.6 \%(1005 / 156,152)$ & $0.5 \%(3577 / 657,405)$ \\
\hline California & $1.6 \%(8478 / 530,788)$ & $0.8 \%(4850 / 649,681)$ & $0.6 \%(15,265 / 2,446,653)$ \\
\hline
\end{tabular}


Table 1 (continued)

\begin{tabular}{llll}
\hline State & $\mathbf{2 0 0 1 - 2 0 0 7}[\mathbf{1 ]}$ & $\mathbf{2 0 1 0 - 2 0 1 2 ~ [ 2 ] ~}$ & $\mathbf{2 0 1 3 - 2 0 1 9}$ \\
\hline Colorado & $0.4 \%(1028 / 261,358)$ & $0.7 \%(1182 / 171,057)$ & $0.9 \%(5961 / 690,515)$ \\
Hawaii & $\mathrm{NR}$ & $1.5 \%(240 / 16,548)$ & $0.7 \%(816 / 124,893)$ \\
Idaho & $0.6 \%(32 / 5748)$ & $0.5 \%(68 / 14,253)$ & $0.4 \%(210 / 48,509)$ \\
Montana & $0.6 \%(16 / 2801)$ & $0.5 \%(23 / 4950)$ & $0.7 \%(165 / 23,827)$ \\
Nevada & $1.2 \%(74 / 6180)$ & $0.5 \%(165 / 32,951)$ & $0.6 \%(688 / 119,315)$ \\
New Mexico & $1.8 \%(427 / 23,429)$ & $1.5 \%(761 / 49,628)$ & $1.4 \%(2077 / 149,284)$ \\
Oregon & $0.8 \%(235 / 29,176)$ & $0.7 \%(344 / 51,964)$ & $0.6 \%(1355 / 237,911)$ \\
Utah & $0.6 \%(11 / 1,904)$ & $0.7 \%(73 / 10,886)$ & $0.5 \%(248 / 50,016)$ \\
Washington & $1.0 \%(39 / 4,099)$ & $0.9 \%(136 / 16,026)$ & $0.6 \%(986 / 157,038)$ \\
Wyoming & $1.2 \%(10 / 700)$ & $0.6 \%(27 / 4285)$ & $1.1 \%(222 / 19,882)$ \\
Region & $1.2 \%(10,970 / 919,992)$ & $0.8 \%(8887 / 1,178,947)$ & $0.7 \%(31,624 / 4,729,016)$ \\
Overall & $1.4 \%(43,500 / 3,182,301)$ & $1.3 \%(142,426 / 10,734,132)$ & $1.4 \%(651,347 / 47,254,819)$ \\
\hline
\end{tabular}

\section{Discussion}

The present study is the third in a series which taken together describe nearly 2 decades of results and constitutes the largest ever reported survey of dogs for multiple vector-borne infections, expanding on our previous publications by including data from the past 7 years and 4- to 30 -times more canine test results $[1,2]$. These data represent findings from annual testing of approximately $7 \%$ to $12 \%$ of the estimated 60 million pet dogs that receive annual veterinary care in the US [26] and thus provide valuable insights into canine infection with heartworm, infestation with ticks, and past or current infection with several tick-borne disease agents. Positive results for all four canine vector-borne agents considered (heartworm, Borrelia burgdorferi, Ehrlichia spp., and Anaplasma spp.) were found in every state in the US (Tables 1, 2, 3, 4), the first time we have observed national evidence of all four types of infections in the 17 years of data included in these surveys $[1,2]$. Because data are anonymized, we cannot exclude the possibility of repeated testing events or of identifying evidence of infections acquired in a different geographic location. Nonetheless, a number of key trends are evident in the geographic distribution (Figs. 1, $2,3,4)$ and relative prevalence of percent positive results in different regions (Tables 1, 2, 3, 4).

For canine heartworm infection as determined by detection of antigen, the data in the present paper suggest that overall prevalence in well-cared-for pet dogs has remained largely unchanged since national surveys using similar sample sets were first reported [1] and that percent positive test results from pet dogs have decreased in southern states (Table 1), from $3.9 \%$ of test results from 2001 to 2007 [1] to $2.6 \%$ of test results from 2013 to 2019. Interestingly, during a similar time period, other researchers reported a significant increase in the prevalence of heartworm infection in the USA, the most marked of which was observed in the South [11, 12, 27, 28], although regional areas where prevalence was clearly decreasing were also identified [27]. Apparent discrepancies between the data in the present article and those reported by others may be due to differences in testing platforms, survey methods, or patient profile. The reports showing an apparent increase in percent positive test results included data from multiple diagnostic laboratories [29] whereas the present paper used only data from practices using well-validated IDEXX tests, which may be a source of selection bias. Surveys of the number of dogs treated for heartworm are useful but cannot be directly compared to infection prevalence trends, and artificial increases in percent positive results can be seen when testing is used primarily for diagnostic verification of a suspected infection rather than for routine screening $[28,29]$. For example, the similar percent positive test results in dogs in Alaska (1.4\%) and Florida (1.4\%) in the present study likely reflect targeted testing by Alaska veterinarians based on a travel history compared to routine screening of dogs protected from infection by preventives despite intense transmission pressure in Florida [30]. Nonetheless, heartworm is a preventable infection, and the finding that $1.4 \%$ of pet dogs receiving veterinary care in the USA, or approximately 840,000 pet dogs overall, are identified as infected with this potentially fatal parasite each year, is dispiriting.

Canine infection with $B$. burgdorferi remains widespread, with antibodies detected in $5.1 \%$ of dogs in the present study overall and $12.1 \%$ of dogs in the Northeast. Significant increases in percent positive test results were evident in some areas of the upper South, including West Virginia and North Carolina, consistent with other reports of geographic spread of the maintenance cycle for this pathogen $[10,13,31]$. At the same time, decreased statewide seroprevalence of antibodies to B. burgdorferi, 
Table 2 Borrelia burgdorferi antibody percent positive test results (number positive/number tested) by region and state from dogs tested in the US from 2001 to 2007 [1], 2010 to 2012 [2], and 2013 to 2019

\begin{tabular}{|c|c|c|c|}
\hline State & 2001-2007 [1] & 2010-2012 [2] & 2013-2019 \\
\hline \multicolumn{4}{|l|}{ Northeast } \\
\hline Connecticut & $18.1 \%(1846 / 10,209)$ & $18.0 \%(33,071 / 183,787)$ & $15.5 \%(134,875 / 871,389)$ \\
\hline Delaware & $11.2 \%(516 / 4595)$ & $9.5 \%(4671 / 49,126)$ & $5.9 \%(10,934 / 186,675)$ \\
\hline District of Columbia & NR & $8.2 \%(574 / 7029)$ & $8.9 \%(6227 / 69,650)$ \\
\hline Maine & $11.6 \%(3269 / 28,230)$ & $13.5 \%(29,860 / 221,556)$ & $13.8 \%(87,442 / 635,002)$ \\
\hline Maryland & $12.6 \%(2882 / 22,945)$ & $10.0 \%(27,348 / 273,406)$ & $6.9 \%(80,393 / 1,157,374)$ \\
\hline Massachusetts & $19.8 \%(6729 / 33,915)$ & $18.3 \%(74,429 / 406,493)$ & $15.3 \%(256,688 / 1,679,429)$ \\
\hline New Hampshire & $12.9 \%(2343 / 18,122)$ & $15.8 \%(20,447 / 129,842)$ & $13.1 \%(73,199 / 556,671)$ \\
\hline New Jersey & $14.2 \%(2913 / 20,575)$ & $13.1 \%(38,695 / 295,084)$ & $9.8 \%(102,967 / 1,047,889)$ \\
\hline New York & $7.1 \%(5781 / 81,305)$ & $9.5 \%(50,802 / 536,978)$ & $10.5 \%(241,549 / 2,305,462)$ \\
\hline Pennsylvania & $9.4 \%(3869 / 40,948)$ & $12.9 \%(74,481 / 579,657)$ & $13.2 \%(291,604 / 2,211,655)$ \\
\hline Rhode Island & $14.3 \%(933 / 6,508)$ & $15.7 \%(10,001 / 63,797)$ & $12.9 \%(18,672 / 144,716)$ \\
\hline Vermont & $9.9 \%(368 / 3,718)$ & $14.8 \%(8833 / 59,518)$ & $14.3 \%(30,759 / 215,341)$ \\
\hline Region & $11.6 \%(31,449 / 271,070)$ & $13.3 \%(373,212 / 2,806,273)$ & $12.1 \%(1,335,309 / 11,081,253)$ \\
\hline \multicolumn{4}{|l|}{ Midwest } \\
\hline Illinois & $1.0 \%(324 / 31,976)$ & $3.0 \%(8413 / 277,352)$ & $2.8 \%(44,155 / 1,554,905)$ \\
\hline Indiana & $1.1 \%(231 / 20,515)$ & $3.5 \%(3961 / 112,480)$ & $3.7 \%(26,769 / 721,305)$ \\
\hline lowa & $0.9 \%(149 / 17,390)$ & $2.9 \%(3236 / 111,522)$ & $3.8 \%(17,822 / 472,821)$ \\
\hline Kansas & $0.1 \%(6 / 5473)$ & $0.5 \%(263 / 52,435)$ & $0.2 \%(458 / 217,196)$ \\
\hline Michigan & $0.6 \%(431 / 67,625)$ & $1.2 \%(2936 / 236,875)$ & $1.5 \%(24,299 / 1,569,693)$ \\
\hline Minnesota & $9.5 \%(7267 / 76,610)$ & $8.6 \%(20,159 / 234,564)$ & $7.9 \%(75,183 / 955,737)$ \\
\hline Missouri & $0.2 \%(59 / 24,095)$ & $0.6 \%(616 / 108,580)$ & $0.4 \%(1722 / 477,732)$ \\
\hline Nebraska & $0.1 \%(5 / 4282)$ & $2.0 \%(91 / 4489)$ & $0.4 \%(222 / 51,900)$ \\
\hline North Dakota & $3.0 \%(136 / 4558)$ & $5.4 \%(893 / 16,560)$ & $4.4 \%(3,898 / 88,388)$ \\
\hline Ohio & $0.2 \%(140 / 61,138)$ & 0.7\% (1970/278,493) & $1.4 \%(21,577 / 1,513,499)$ \\
\hline South Dakota & $0.3 \%(1 / 358)$ & $6.0 \%(270 / 4,497)$ & $0.7 \%(376 / 53,478)$ \\
\hline Wisconsin & $10.2 \%(6018 / 59,070)$ & $11.8 \%(33,217 / 282,663)$ & $8.7 \%(100,656 / 1,162,272)$ \\
\hline Region & $4.0 \%(14,767 / 373,090)$ & $4.4 \%(76,025 / 1,720,510)$ & $3.6 \%(317,137 / 8,838,926)$ \\
\hline \multicolumn{4}{|l|}{ Southeast } \\
\hline Alabama & $0.1 \%(27 / 18,998)$ & $0.7 \%(367 / 53,340)$ & $0.3 \%(879 / 284,182)$ \\
\hline Arkansas & $0.1 \%(7 / 8391)$ & $0.5 \%(220 / 42,776)$ & $0.3 \%(420 / 159,161)$ \\
\hline Florida & $0.5 \%(256 / 54,982)$ & $1.0 \%(3832 / 403,886)$ & $0.7 \%(11,285 / 1,588,284)$ \\
\hline Georgia & $0.3 \%(77 / 23,333)$ & $0.8 \%(985 / 124,665)$ & $0.4 \%(2808 / 707,236)$ \\
\hline Kentucky & $0.2 \%(45 / 18,935)$ & $1.5 \%(847 / 56,049)$ & $1.5 \%(5367 / 346,951)$ \\
\hline Louisiana & $0.1 \%(9 / 11,197)$ & $0.4 \%(48 / 12,449)$ & $0.4 \%(456 / 120,604)$ \\
\hline Mississippi & $0.0 \%(1 / 2198)$ & $0.7 \%(43 / 6643)$ & $0.2 \%(152 / 68,995)$ \\
\hline North Carolina & $1.3 \%(263 / 20,783)$ & $1.9 \%(4,837 / 249,170)$ & $2.2 \%(40,435 / 1,797,246)$ \\
\hline Oklahoma & $0.2 \%(19 / 11,549)$ & $0.6 \%(445 / 70,753)$ & $0.2 \%(621 / 301,050)$ \\
\hline South Carolina & $1.3 \%(148 / 11,562)$ & $1.0 \%(857 / 82,684)$ & $1.2 \%(5296 / 453,004)$ \\
\hline Tennessee & $0.2 \%(47 / 18,891)$ & $0.6 \%(670 / 111,314)$ & 0.7\% (3247/456,799) \\
\hline Texas & $0.2 \%(91 / 58,088)$ & $0.5 \%(1935 / 432,919)$ & $0.2 \%(4038 / 1,778,128)$ \\
\hline Virginia & $6.7 \%(1924 / 28,787)$ & $9.7 \%(33,994 / 350,489)$ & $7.9 \%(148,215 / 1,886,576)$ \\
\hline West Virginia & $0.3 \%(9 / 2942)$ & $3.5 \%(2152 / 61,437)$ & $8.0 \%(20,034 / 249,841)$ \\
\hline Region & $1.0 \%(2923 / 290,636)$ & $2.5 \%(51,232 / 2,058,574)$ & $2.4 \%(243,253 / 10,198,057)$ \\
\hline \multicolumn{4}{|l|}{ West } \\
\hline Alaska & NR & NR & $3.6 \%(16 / 444)$ \\
\hline Arizona & $0.4 \%(4 / 992)$ & $0.8 \%(424 / 55,893)$ & $0.7 \%(2,421 / 345,481)$ \\
\hline California & $1.8 \%(540 / 29,454)$ & $1.6 \%(4447 / 270,516)$ & $1.0 \%(13,425 / 1,280,960)$ \\
\hline
\end{tabular}


Table 2 (continued)

\begin{tabular}{llll}
\hline State & $\mathbf{2 0 0 1 - 2 0 0 7}[\mathbf{1 ]}$ & $\mathbf{2 0 1 0 - 2 0 1 2}[\mathbf{2}]$ & $\mathbf{2 0 1 3 - 2 0 1 9}$ \\
\hline Colorado & $0.4 \%(49 / 11,557)$ & $1.0 \%(192 / 19,489)$ & $0.8 \%(1354 / 175,609)$ \\
Hawaii & $\mathrm{NR}$ & $0.3 \%(6 / 2360)$ & $0.2 \%(122 / 51,379)$ \\
Idaho & $0.3 \%(1 / 369)$ & $3.6 \%(6 / 169)$ & $0.7 \%(107 / 15,917)$ \\
Montana & $\mathrm{NR}$ & $0(0 / 37)$ & $1.4 \%(79 / 5842)$ \\
Nevada & $\mathrm{NR}$ & $0.6 \%(74 / 12,286)$ & $0.6 \%(178 / 31,574)$ \\
New Mexico & $0.3 \%(7 / 2060)$ & $0.7 \%(185 / 26,714)$ & $0.4 \%(316 / 72,549)$ \\
Oregon & $2.8 \%(77 / 2798)$ & $1.7 \%(312 / 17,893)$ & $1.0 \%(1110 / 115,018)$ \\
Utah & $0(0 / 93)$ & $1.2 \%(9 / 784)$ & $0.8 \%(62 / 8231)$ \\
Washington & $0(0 / 33)$ & $1.5 \%(64 / 4338)$ & $0.5 \%(314 / 60,704)$ \\
Wyoming & $0(0 / 184)$ & $1.9 \%(7 / 361)$ & $0.9 \%(47 / 4968)$ \\
Region & $1.4 \%(678 / 47,540)$ & $1.4 \%(5726 / 410,840)$ & $0.9 \%(19,551 / 2,168,676)$ \\
Overall & $5.1 \%(49,817 / 982,336)$ & $7.2 \%(509,195 / 6,996,197)$ & $5.9 \%(1,915,250 / 32,286,912)$ \\
\hline
\end{tabular}

in some cases by more than $40 \%$, was evident in several states where Lyme disease has long been endemic or hyperendemic, including Connecticut, Massachusetts, New Jersey, Delaware, and Maryland (Table 2), a trend that has been previously reported [10]. Canine infection with $B$. burgdorferi varies widely even in relatively focal areas [17] and can be prevented with a combination of tick control and vaccination [32]. Increased adherence to these recommendations, including the widespread use of systemic isoxazoline acaricides, which first became available in the USA in 2014, would be expected to result in decreased percent positive test results in dogs over time. However, B. burgdorferi infection remains common, particularly in areas of the Northeast where I. scapularis vector populations are intense or expanding, and canine seroprevalence to $B$. burgdorferi continues to increase in northern New England, western New York, and western Pennsylvania [10,33]. In other regions, such as in states along the southern border of the USA, autochthonous transmission of B. burgdorferi has not been documented, but antibodies to $B$. burgdorferi may occasionally be identified in dogs that move to that region, creating confusion when survey results are not carefully interpreted in context [34, 35].

Results of the current serosurvey demonstrate an increase in the number of dogs with antibodies to Ehrlichia spp. in nearly all states within the US. Since the publication of the 2010-2012 seroprevalence results, the ELISA test for antibodies to Ehrlichia spp. was modified to include a new peptide for the detection of antibodies to E. ewingii [19]. Canine seroreactivity to this new target, as well as the increase in seropositive results observed particularly across the Southeast, is consistent with regional results from a study where canine serum samples were obtained from academic and private veterinary hospitals [6]. In that earlier study, antibodies to $E$. canis were more frequently detected in dogs in the southcentral region where the brown dog tick vectors predominate, while antibodies to both E. ewingii and E. chaffeensis were more prevalent in dogs from a band of states across the upper south, where A. americanum is most common [6]. Indeed, $A$. americanum, the tick responsible for transmitting $E$. ewingii, is highly prevalent across the Southeast region with evidence of geographic spread to states within the Midwest and Northeast [15, 36]. Even before the test could detect antibodies to $E$. ewingii, the Midwest region had evidence of canine seroreactivity to Ehrlichia spp. [1, 2]. It is not known if this previous and continued seroreactivity is associated with the novel Ehrlichia muris subsp. euclairensis reported there [37] since only one clinical infection with this pathogen has been documented in the dog [38]. Because the different Ehrlichia spp. antibodies are detected by reactivity on a single spot or microtiter well of the test, it is not possible to determine the infecting species of Ehrlichia. While geographic location and predominant tick species may provide some guidance, elucidating the causative Ehrlichia species is becoming increasingly difficult because of expanding tick ranges and the transport of dogs across the country for adoption.

The seroprevalence of Anaplasma spp., although decreased slightly in the Midwest and certain Northeastern states, remained largely unchanged relative to the previous report [2]. In much of the northern USA, antibodies to Anaplasma spp. (presumably to A. phagocytophilum) were detected less frequently than antibodies to $B$. burgdorferi in most states despite transmission by the same species of tick, Ixodes scapularis. Surveys 
Table 3 Ehrlichia spp. antibody percent positive test results (number positive/number tested) by region and state from dogs tested in the US from 2001 to 2007 [1], 2010 to 2012 [2], and 2013 to 2019

\begin{tabular}{|c|c|c|c|}
\hline State & 2001-2007 [1] & $2010-2012[2]$ & 2013-2019 \\
\hline \multicolumn{4}{|l|}{ Northeast } \\
\hline Connecticut & $0.2 \%(21 / 10,209)$ & $0.8 \%(1434 / 183,776)$ & $1.5 \%(13,159 / 870,092)$ \\
\hline Delaware & $1.0 \%(48 / 4595)$ & $2.3 \%(1,114 / 49,131)$ & $4.9 \%(9075 / 186,675)$ \\
\hline District of Columbia & NR & $1.6 \%(113 / 7029)$ & $3.8 \%(2679 / 69,650)$ \\
\hline Maine & $0.1 \%(39 / 28,230)$ & $0.6 \%(1214 / 221,555)$ & $1.4 \%(8909 / 635,005)$ \\
\hline Maryland & $0.7 \%(165 / 22,945)$ & $1.9 \%(5107 / 273,382)$ & $4.6 \%(52,771 / 1,157,266)$ \\
\hline Massachusetts & $0.3 \%(107 / 33,915)$ & $0.8 \%(3315 / 406,476)$ & $1.8 \%(30,583 / 1,679,373)$ \\
\hline New Hampshire & $0.2 \%(36 / 18,122)$ & $0.7 \%(949 / 129,829)$ & $1.7 \%(9499 / 556,670)$ \\
\hline New Jersey & $0.4 \%(89 / 20,575)$ & $1.2 \%(3638 / 295,047)$ & $3.1 \%(32,278 / 1,046,276)$ \\
\hline New York & $0.2 \%(179 / 81,305)$ & $0.6 \%(3176 / 536,968)$ & $1.4 \%(32,835 / 2,304,678)$ \\
\hline Pennsylvania & $0.2 \%(80 / 40,948)$ & $0.6 \%(3364 / 579,608)$ & $1.1 \%(24,835 / 2,211,622)$ \\
\hline Rhode Island & $0.1 \%(6 / 6508)$ & $0.3 \%(206 / 63,796)$ & $1.4 \%(1958 / 144,718)$ \\
\hline Vermont & $0.2 \%(7 / 3718)$ & $0.6 \%(381 / 59,515)$ & $1.6 \%(3420 / 215,341)$ \\
\hline Region & $0.3 \%(777 / 271,070)$ & $0.9 \%(24,011 / 2,806,112)$ & $2.0 \%(222,001 / 11,077,366)$ \\
\hline \multicolumn{4}{|l|}{ Midwest } \\
\hline Illinois & $0.4 \%(135 / 31,976)$ & $0.8 \%(2155 / 277,174)$ & $1.8 \%(28,173 / 1,554,356)$ \\
\hline Indiana & $0.3 \%(54 / 20,515)$ & $1.3 \%(1480 / 112,477)$ & $1.8 \%(13,048 / 721,278)$ \\
\hline lowa & $0.4 \%(61 / 17,390)$ & $0.7 \%(751 / 111,518)$ & $1.4 \%(6435 / 472,492)$ \\
\hline Kansas & $2.2 \%(119 / 5,473)$ & $2.3 \%(1228 / 52,429)$ & 4.6\% (9982/217,197) \\
\hline Michigan & $0.1 \%(34 / 67,625)$ & $0.3 \%(781 / 236,798)$ & $0.6 \%(10,126 / 1,569,688)$ \\
\hline Minnesota & $0.3 \%(202 / 76,610)$ & $0.6 \%(1426 / 234,558)$ & $1.2 \%(11,517 / 955,740)$ \\
\hline Missouri & $1.9 \%(462 / 24,095)$ & $5.4 \%(5888 / 108,573)$ & $10.4 \%(49,485 / 477,734)$ \\
\hline Nebraska & $0.3 \%(13 / 4282)$ & $1.6 \%(70 / 4485)$ & $1.8 \%(956 / 51,900)$ \\
\hline North Dakota & $0.0 \%(1 / 4558)$ & $0.3 \%(55 / 16,560)$ & $0.6 \%(496 / 88,388)$ \\
\hline Ohio & $0.1 \%(79 / 61,138)$ & $0.6 \%(1727 / 278,437)$ & $1.1 \%(16,838 / 1,513,496)$ \\
\hline South Dakota & $0(0 / 358)$ & $0.6 \%(25 / 4497)$ & $0.5 \%(286 / 53,477)$ \\
\hline Wisconsin & $0.3 \%(194 / 59,070)$ & $0.6 \%(1751 / 282,662)$ & $1.2 \%(13,900 / 1,162,273)$ \\
\hline Region & $0.4 \%(1354 / 373,090)$ & $1.0 \%(17,337 / 1,720,168)$ & $1.8 \%(161,242 / 8,838,019)$ \\
\hline \multicolumn{4}{|l|}{ Southeast } \\
\hline Alabama & $0.3 \%(64 / 18,998)$ & $1.6 \%(856 / 53,339)$ & $3.5 \%(10,024 / 284,181)$ \\
\hline Arkansas & $3.9 \%(324 / 8391)$ & $9.4 \%(4029 / 42,774)$ & $18.4 \%(29,341 / 159,161)$ \\
\hline Florida & $0.8 \%(425 / 54,982)$ & $1.2 \%(4644 / 403,622)$ & $1.8 \%(28,518 / 1,588,286)$ \\
\hline Georgia & $1.9 \%(444 / 23,333)$ & $2.6 \%(3290 / 124,637)$ & $3.7 \%(26,377 / 707,157)$ \\
\hline Kentucky & $0.8 \%(152 / 18,935)$ & $4.3 \%(2420 / 56,027)$ & $6.9 \%(23,837 / 346,952)$ \\
\hline Louisiana & $0.2 \%(18 / 11,197)$ & $1.1 \%(140 / 12,406)$ & $1.9 \%(2264 / 120,602)$ \\
\hline Mississippi & $3.1 \%(68 / 2198)$ & $4.6 \%(308 / 6637)$ & $7.0 \%(4841 / 68,995)$ \\
\hline North Carolina & $2.1 \%(431 / 20,783)$ & $4.6 \%(11,431 / 249,132)$ & $6.4 \%(115,377 / 1,797,218)$ \\
\hline Oklahoma & $3.8 \%(439 / 11,549)$ & $5.4 \%(3,847 / 70,751)$ & $8.3 \%(24,845 / 301,051)$ \\
\hline South Carolina & $0.8 \%(95 / 11,562)$ & $1.4 \%(1151 / 82,677)$ & $2.6 \%(11,655 / 453,006)$ \\
\hline Tennessee & $2.3 \%(428 / 18,891)$ & $3.0 \%(3307 / 111,312)$ & $8.1 \%(37,150 / 456,799)$ \\
\hline Texas & $0.8 \%(441 / 58,088)$ & $1.8 \%(7659 / 432,799)$ & $2.2 \%(38,424 / 1,778,110)$ \\
\hline Virginia & $1.8 \%(532 / 28,787)$ & $6.2 \%(21,770 / 350,437)$ & $9.4 \%(176,931 / 1,886,580)$ \\
\hline West Virginia & $0.1 \%(4 / 2942)$ & $0.6 \%(339 / 61,434)$ & $1.2 \%(3091 / 249,842)$ \\
\hline Region & $1.3 \%(3865 / 290,636)$ & $3.2 \%(65,191 / 2.057,984)$ & $5.2 \%(532,675 / 10,197,940)$ \\
\hline \multicolumn{4}{|l|}{ West } \\
\hline Alaska & NR & $N R$ & $3.8 \%(17 / 444)$ \\
\hline Arizona & $3.2 \%(32 / 992)$ & $2.4 \%(1349 / 55,865)$ & $2.8 \%(9628 / 34,5481)$ \\
\hline California & $0.8 \%(225 / 29,454)$ & $0.8 \%(2258 / 270,190)$ & $1.1 \%(14,600 / 1,280,960)$ \\
\hline
\end{tabular}


Table 3 (continued)

\begin{tabular}{llll}
\hline State & $\mathbf{2 0 0 1 - 2 0 0 7}[\mathbf{1 ]}$ & $\mathbf{2 0 1 0 - 2 0 1 2}[\mathbf{2}]$ & $\mathbf{2 0 1 3 - 2 0 1 9}$ \\
\hline Colorado & $0.2 \%(19 / 11,557)$ & $1.1 \%(217 / 19,467)$ & $2.2 \%(3842 / 175,609)$ \\
Hawaii & $\mathrm{NR}$ & $7.0 \%(166 / 2359)$ & $2.7 \%(1368 / 51,378)$ \\
Idaho & $0(0 / 369)$ & $0.6 \%(1 / 167)$ & $1.0 \%(167 / 15,917)$ \\
Montana & $\mathrm{NR}$ & $0(0 / 36)$ & $1.5 \%(86 / 5842)$ \\
Nevada & $\mathrm{NR}$ & $0.5 \%(59 / 12,278)$ & $0.9 \%(284 / 31,574)$ \\
New Mexico & $1.0 \%(21 / 2060)$ & $3.2 \%(858 / 26,706)$ & $3.3 \%(2393 / 72,549)$ \\
Oregon & $0.1 \%(2 / 2798)$ & $0.6 \%(111 / 17,879)$ & $0.9 \%(1043 / 115,016)$ \\
Utah & $0(0 / 93)$ & $0.5 \%(4 / 783)$ & $1.0 \%(79 / 8231)$ \\
Washington & $0(0 / 33)$ & $2.5 \%(109 / 4330)$ & $1.2 \%(734 / 60,702)$ \\
Wyoming & $0(0 / 184)$ & $0.6 \%(2 / 359)$ & $2.7 \%(136 / 4968)$ \\
Region & $0.6 \%(299 / 47,540)$ & $1.3 \%(5134 / 410,419)$ & $1.6 \%(34,377 / 2,168,671)$ \\
Overall & $0.6 \%(6295 / 982,336)$ & $1.6 \%(111,673 / 6,994,683)$ & $2.9 \%(950,295 / 32,281,996)$ \\
\hline
\end{tabular}

conducted in areas of the Northeast and upper Midwest have found that 3-10 times as many Ixodes scapularis nymphs and adult ticks contain B. burgdorferi DNA compared to $A$. phagocytophilum DNA [39-41]. In a recent study which tested I. scapularis removed from dogs and cats in the Northeastern USA, $17.8 \%$ were infected with B. burgdorferi and $2.6 \%$ with $A$. phagocytophilum [42]. A greater proportion of ticks harboring $B$. burgdorferi could make it more likely that dogs would be exposed to this pathogen and perhaps contribute to the observed difference in seroprevalence observed with Anaplasma in these regions. In the southcentral and southwestern states, increased prevalence of Anaplasma spp. is more likely due to $A$. platys transmitted by brown dog ticks, which are commonly present in this region $[43,44]$. The use of systemic and topical acaracides may help to prevent anaplasmosis and Lyme borreliosis as both have been reported to reduce $I$. scapularis transmission of $B$. burgdorferi and A. phagocytophilum to dogs [45-47].

Key limitations of the present study include lack of clinical information about individual dogs that may have provided insight into veterinarians' reasons for testing. Selective testing, which may be more common when dogs present with clinical signs characteristic of a given vector-borne disease and owner-reported travel to an area where a suspected pathogen is endemic, would be expected to create a positive bias in percent positive test rates in non-endemic areas. We addressed this concern, in part, by omitting counties reporting few test results (less than 210 over 7 years) from the maps (Figs. 1, 2, 3, 4 ) as we have done in both previous reports $[1,2]$. Nonetheless, dogs testing positive in regions where pathogens are not known to be transmitted are most likely due to translocation of infected dogs. Large-scale relocation of dogs from heartworm-endemic areas to counties where infections are rare has been associated with an increase in local prevalence of dogs testing positive for D. immitis [12]. Smaller studies have documented past travel in dogs that test positive for B. burgdorferi in areas where disease is not known to be locally transmitted [48, 49]. Canine serologic data alone cannot confirm pathogens are established in a given area, and multiple lines of evidence, including directly testing vector mosquitoes or ticks, are necessary to confirm apparent transmission of vectorborne pathogens in new regions [1, 2, 12, 13, 47, 48]. Similarly, while the present study confirms that canine serology remains a useful predictor of where corresponding tick-borne diseases are most likely to be reported in people, limitations in both human and canine datasets suggest this finding must be interpreted with appropriate caution [2, 48-50]. Nonetheless, routine screening of dogs for vector-borne infections, as recommended by veterinary advisory groups to allow early detection of infection in individual patients [3, 4, 32], has a clear, albeit secondary, veterinary and public health benefit: careful analysis of the resulting aggregate data enhances our understanding of the changing pattern of the distribution of these vector-borne pathogens across the USA $[1,2]$.

\section{Conclusions}

In this study-the third large-scale vector-borne disease serosurvey conducted since we began analyzing multi-year data sets in 2001-we have provided a comprehensive update on the frequency of positive test results for the most common canine vector-borne 
Table 4 Anaplasma spp. antibody percent positive test results (number positive/number tested) by region and state from dogs tested in the US from 2001 to 2007 [1], 2010 to 2012 [2], and 2013 to 2019

\begin{tabular}{|c|c|c|c|}
\hline State & 2001-2007 [1] & 2010-2012 [2] & 2013-2019 \\
\hline \multicolumn{4}{|l|}{ Northeast } \\
\hline Connecticut & $21.8 \%(1499 / 6887)$ & $20.3 \%(37,390 / 183,792)$ & $15.4 \%(134,039 / 870,093)$ \\
\hline Delaware & $1.1 \%(48 / 4315)$ & $1.0 \%(460 / 47,722)$ & $0.9 \%(1704 / 183,604)$ \\
\hline District of Columbia & NR & $1.6 \%(57 / 3687)$ & $1.6 \%(1096 / 69,650)$ \\
\hline Maine & $5.4 \%(1341 / 24,632)$ & $8.3 \%(18,367 / 220,977)$ & $11.4 \%(72,231 / 634,959)$ \\
\hline Maryland & $1.7 \%(282 / 16,307)$ & $1.6 \%(3887 / 239,461)$ & $1.3 \%(15,227 / 1,149,654)$ \\
\hline Massachusetts & $10.4 \%(2803 / 26,911)$ & $10.7 \%(41,223 / 385,659)$ & $12.4 \%(208,757 / 1,678,729)$ \\
\hline New Hampshire & $4.5 \%(618 / 13,743)$ & $7.7 \%(9605 / 125,054)$ & $11.1 \%(61,104 / 556,329)$ \\
\hline New Jersey & $9.8 \%(1339 / 13,721)$ & $8.5 \%(24,330 / 286,133)$ & $6.3 \%(65,488 / 1,046,199)$ \\
\hline New York & $3.6 \%(1741 / 48,201)$ & $6.1 \%(30,916 / 506,075)$ & $5.9 \%(135,113 / 2,304,237)$ \\
\hline Pennsylvania & $1.6 \%(449 / 27,641)$ & $2.5 \%(13,585 / 536,513)$ & $3.7 \%(81,660 / 2,209,906)$ \\
\hline Rhode Island & $4.7 \%(158 / 3396)$ & $12.8 \%(7477 / 58,211)$ & $9.9 \%(14,368 / 144,485)$ \\
\hline Vermont & $1.7 \%(46 / 2684)$ & $3.7 \%(2189 / 59,517)$ & $7.9 \%(17,096 / 215,341)$ \\
\hline Region & $5.5 \%(10,324 / 188,438)$ & $7.1 \%(189,486 / 2,652,801)$ & $7.3 \%(807,883 / 11,063,186)$ \\
\hline \multicolumn{4}{|l|}{ Midwest } \\
\hline Illinois & $0.4 \%(51 / 11,899)$ & $1.0 \%(2369 / 249,268)$ & $0.6 \%(9947 / 1,553,848)$ \\
\hline Indiana & $0.4 \%(26 / 7084)$ & $0.5 \%(436 / 86,974)$ & $0.4 \%(2755 / 720,622)$ \\
\hline lowa & $0.4 \%(21 / 4840)$ & $0.7 \%(742 / 110,278)$ & $0.5 \%(2451 / 472,000)$ \\
\hline Kansas & $0.5 \%(7 / 1452)$ & $0.4 \%(191 / 49,142)$ & $0.2 \%(492 / 217,126)$ \\
\hline Michigan & $1.2 \%(190 / 16,312)$ & $0.5 \%(1149 / 214,347)$ & $0.5 \%(8458 / 1,569,034)$ \\
\hline Minnesota & $9.8 \%(6002 / 61,374)$ & $9.5 \%(22,338 / 234,565)$ & $6.0 \%(57,553 / 955,732)$ \\
\hline Missouri & $0.3 \%(14 / 5250)$ & $0.4 \%(263 / 73,963)$ & $0.3 \%(1498 / 466,532)$ \\
\hline Nebraska & NR & $0.9 \%(36 / 4143)$ & $0.6 \%(289 / 51,759)$ \\
\hline North Dakota & $2.4 \%(40 / 1692)$ & $3.4 \%(557 / 16,556)$ & $2.6 \%(2265 / 88,388)$ \\
\hline Ohio & $0.1 \%(13 / 14,414)$ & $0.3 \%(691 / 223,187)$ & $0.3 \%(4700 / 1,507,641)$ \\
\hline South Dakota & NR & $12.7 \%(456 / 3599)$ & $0.4 \%(193 / 50,497)$ \\
\hline Wisconsin & $10.5 \%(5,409 / 51,512)$ & $10.7 \%(30,352 / 282,664)$ & $6.1 \%(71,335 / 1,162,247)$ \\
\hline Region & $6.7 \%(11,773 / 175,829)$ & $3.9 \%(59,580 / 1,548,686)$ & $1.8 \%(161,936 / 8,815,426)$ \\
\hline \multicolumn{4}{|l|}{ Southeast } \\
\hline Alabama & $0.1 \%(4 / 4331)$ & $0.3 \%(150 / 46,258)$ & $0.3 \%(703 / 276,999)$ \\
\hline Arkansas & $0.6 \%(10 / 1743)$ & $0.5 \%(178 / 37,465)$ & $0.3 \%(531 / 158,769)$ \\
\hline Florida & $0.5 \%(166 / 31,690)$ & $0.7 \%(2375 / 327,715)$ & $0.6 \%(9277 / 1,581,448)$ \\
\hline Georgia & $0.2 \%(15 / 8856)$ & $0.4 \%(297 / 81,133)$ & $0.2 \%(1747 / 705,485)$ \\
\hline Kentucky & $0.1 \%(5 / 4319)$ & $0.5 \%(165 / 31,795)$ & $0.3 \%(1052 / 339,065)$ \\
\hline Louisiana & $0.1 \%(1 / 707)$ & $0.3 \%(28 / 9501)$ & $0.4 \%(493 / 120,074)$ \\
\hline Mississippi & $0(0 / 300)$ & $0.6 \%(33 / 5295)$ & $0.3 \%(176 / 68,942)$ \\
\hline North Carolina & $0.4 \%(25 / 6841)$ & $0.6 \%(1076 / 196,723)$ & 0.4\% (7947/1,794,296) \\
\hline Oklahoma & $1.2 \%(70 / 5920)$ & $1.0 \%(650 / 68,486)$ & $0.6 \%(1858 / 300,920)$ \\
\hline South Carolina & $0.1 \%(9 / 6507)$ & $0.5 \%(188 / 41,085)$ & $0.4 \%(1834 / 451,566)$ \\
\hline Tennessee & $0.1 \%(4 / 4324)$ & $0.3 \%(284 / 82,326)$ & $0.3 \%(1387 / 456,109)$ \\
\hline Texas & $0.6 \%(90 / 14,788)$ & $1.2 \%(3888 / 336,473)$ & $0.9 \%(15,137 / 1,771,495)$ \\
\hline Virginia & $0.9 \%(96 / 10,195)$ & $1.4 \%(4402 / 311,594)$ & $1.0 \%(18,448 / 1,883,167)$ \\
\hline West Virginia & $0.2 \%(1 / 627)$ & $0.6 \%(332 / 55,483)$ & $0.9 \%(2140 / 248,376)$ \\
\hline Region & $0.5 \%(496 / 101,148)$ & $0.9 \%(14,046 / 1,631,332)$ & $0.6 \%(62,730 / 10,156,711)$ \\
\hline \multicolumn{4}{|l|}{ West } \\
\hline Alaska & NR & NR & $0.9 \%(4 / 444)$ \\
\hline Arizona & $0.7 \%(4 / 583)$ & $0.6 \%(259 / 40,490)$ & $0.8 \%(2669 / 343,274)$ \\
\hline California & $4.8 \%(612 / 12,673)$ & $2.3 \%(5,571 / 255,781)$ & $1.4 \%(17,779 / 1,279,877)$ \\
\hline
\end{tabular}


Table 4 (continued)

\begin{tabular}{llll}
\hline State & $\mathbf{2 0 0 1 - 2 0 0 7}[\mathbf{1 ]}$ & $\mathbf{2 0 1 0 - 2 0 1 2}[\mathbf{2}]$ & $\mathbf{2 0 1 3 - 2 0 1 9}$ \\
\hline Colorado & $0(0 / 86)$ & $1.1 \%(120 / 11,145)$ & $0.7 \%(1,271 / 174,234)$ \\
Hawaii & $\mathrm{NR}$ & $0.9 \%(18 / 1920)$ & $0.6 \%(309 / 51,265)$ \\
Idaho & $0.7 \%(2 / 298)$ & $1.2 \%(2 / 169)$ & $0.43(69 / 15,917)$ \\
Montana & $\mathrm{NR}$ & $5.4 \%(2 / 37)$ & $0.9 \%(55 / 5841)$ \\
Nevada & $\mathrm{NR}$ & $0.4 \%(31 / 8456)$ & $0.3 \%(97 / 31,243)$ \\
New Mexico & $0.3 \%(1 / 289)$ & $1.7 \%(341 / 20,344)$ & $1.2 \%(850 / 72,324)$ \\
Oregon & $7.4 \%(22 / 296)$ & $3.0 \%(475 / 15,807)$ & $1.6 \%(1857 / 1,149,46)$ \\
Utah & $\mathrm{NR}$ & $0.8 \%(6 / 784)$ & $0.4 \%(35 / 8222)$ \\
Washington & $\mathrm{NR}$ & $1.2 \%(49 / 4162)$ & $0.7 \%(444 / 60,629)$ \\
Wyoming & $\mathrm{NR}$ & $0.6 \%(2 / 354)$ & $0.8 \%(38 / 4,966)$ \\
Region & $4.5 \%(641 / 14,225)$ & $2.0 \%(7056 / 359,449)$ & $1.2 \%(25,477 / 2,163,182)$ \\
Overall & $4.8 \%(23,234 / 479,640)$ & $4.4 \%(270,168 / 6,192,268)$ & $3.3 \%(1,058,026 / 32,198,505)$ \\
\hline
\end{tabular}

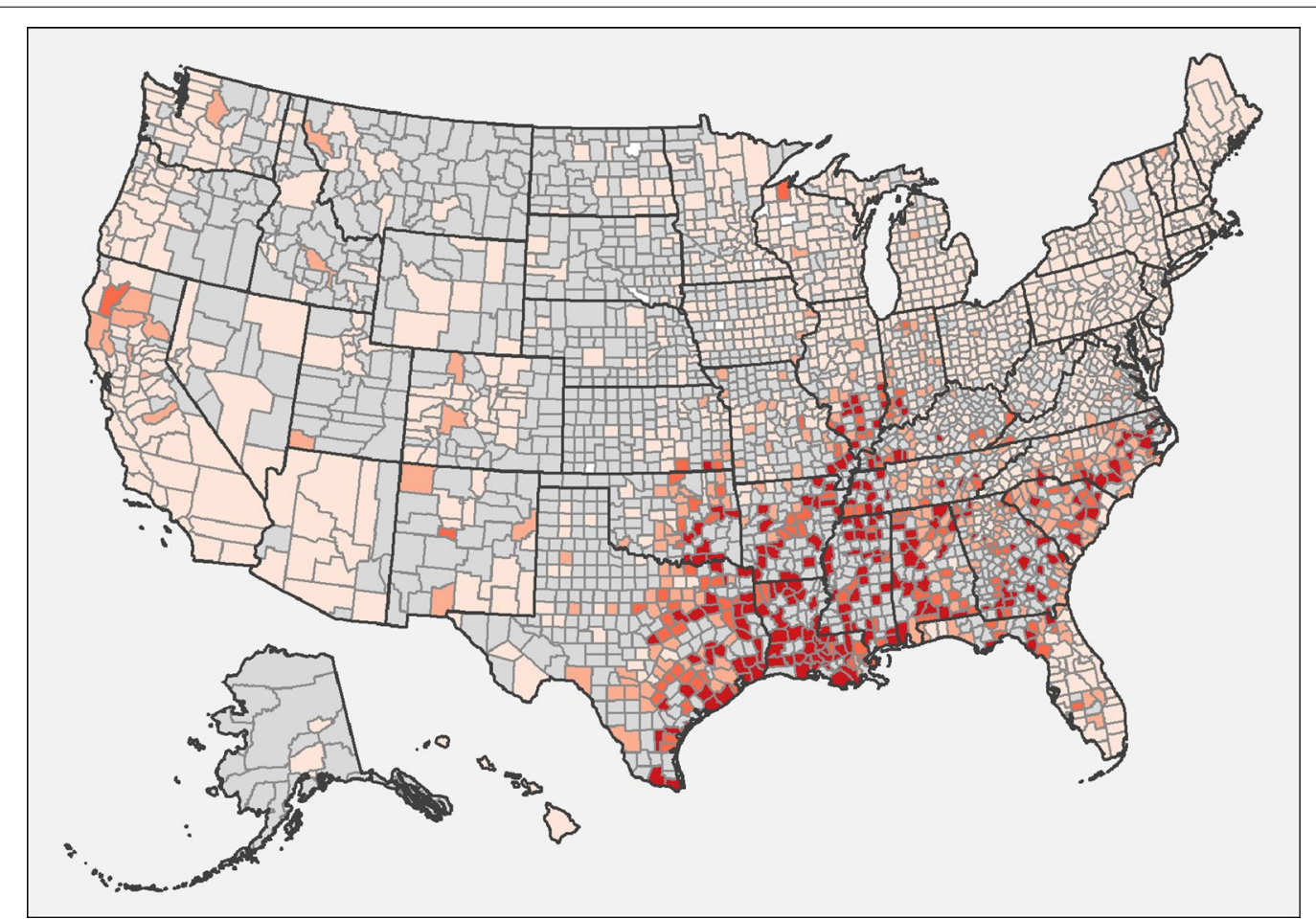

Fig. 1 Evidence of antigen of Dirofilaria immitis in dogs by county, grouped according to percent positive tests. Few results ( $<30$ per year) were received from counties shaded gray, precluding interpretation of the presence of antigen in dogs from these areas. Counties with at least 210 results available for the 7-year period were shaded according to the following code: no dogs reported as positive (0\%, white), $0.1-2.0 \%$ (light pink), $2.1-4.0 \%$ (pink), $4.1-6.0 \%$ (red), and $>6.0 \%$ (dark red)

disease agents in the US. Several important findings were made in this extension of the study series. For the first time, the data demonstrate positive test results for each of the four vector-borne disease agents in all states. This significant finding may be explained by expanding vector range, global climate change, and increasing pet translocation, both for adoptions and for travel. Also unique to this study, the overall incidence of $B$. burgdorferi-positive results decreased relative to prior study periods, driven by the largest 


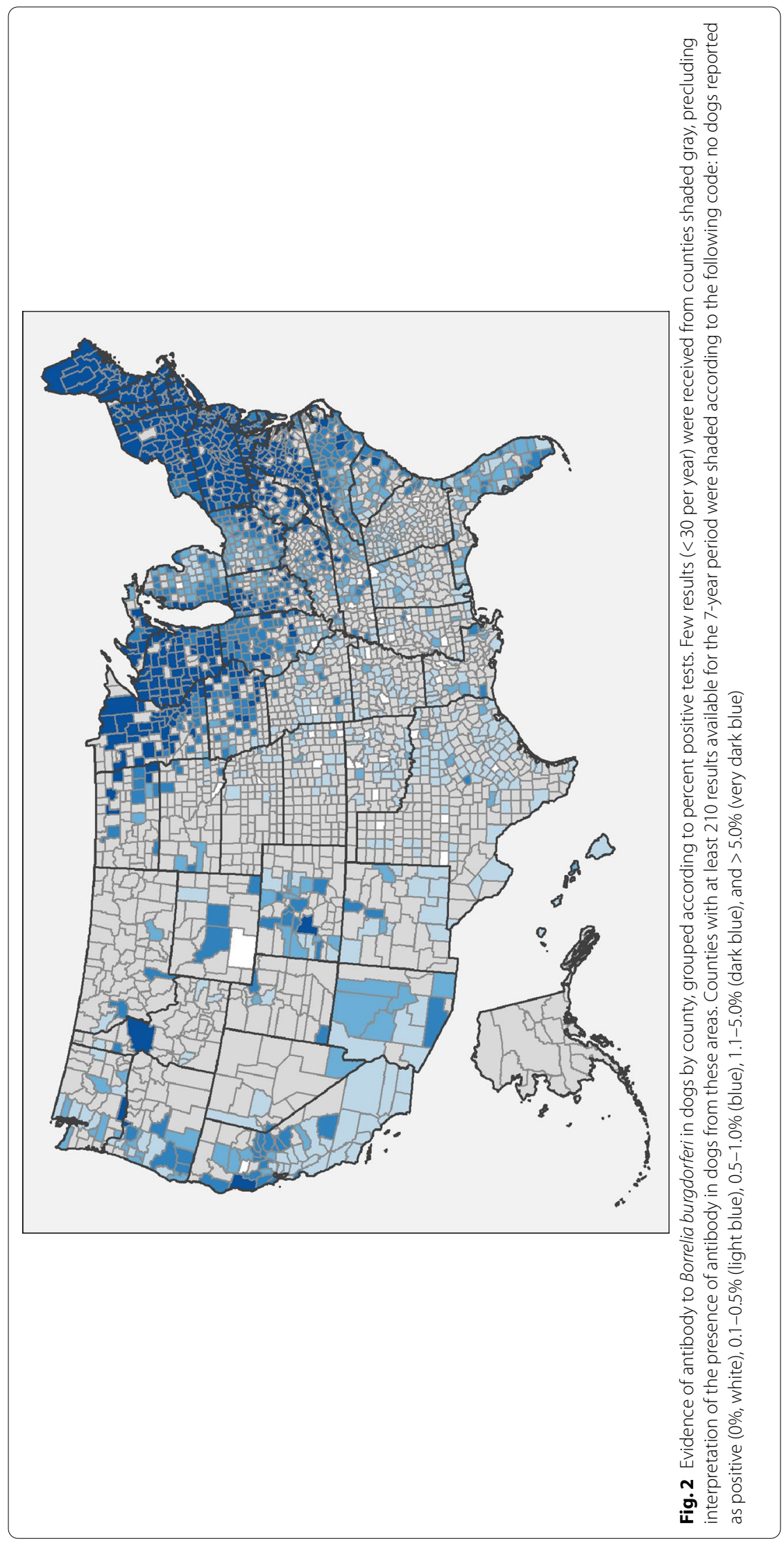




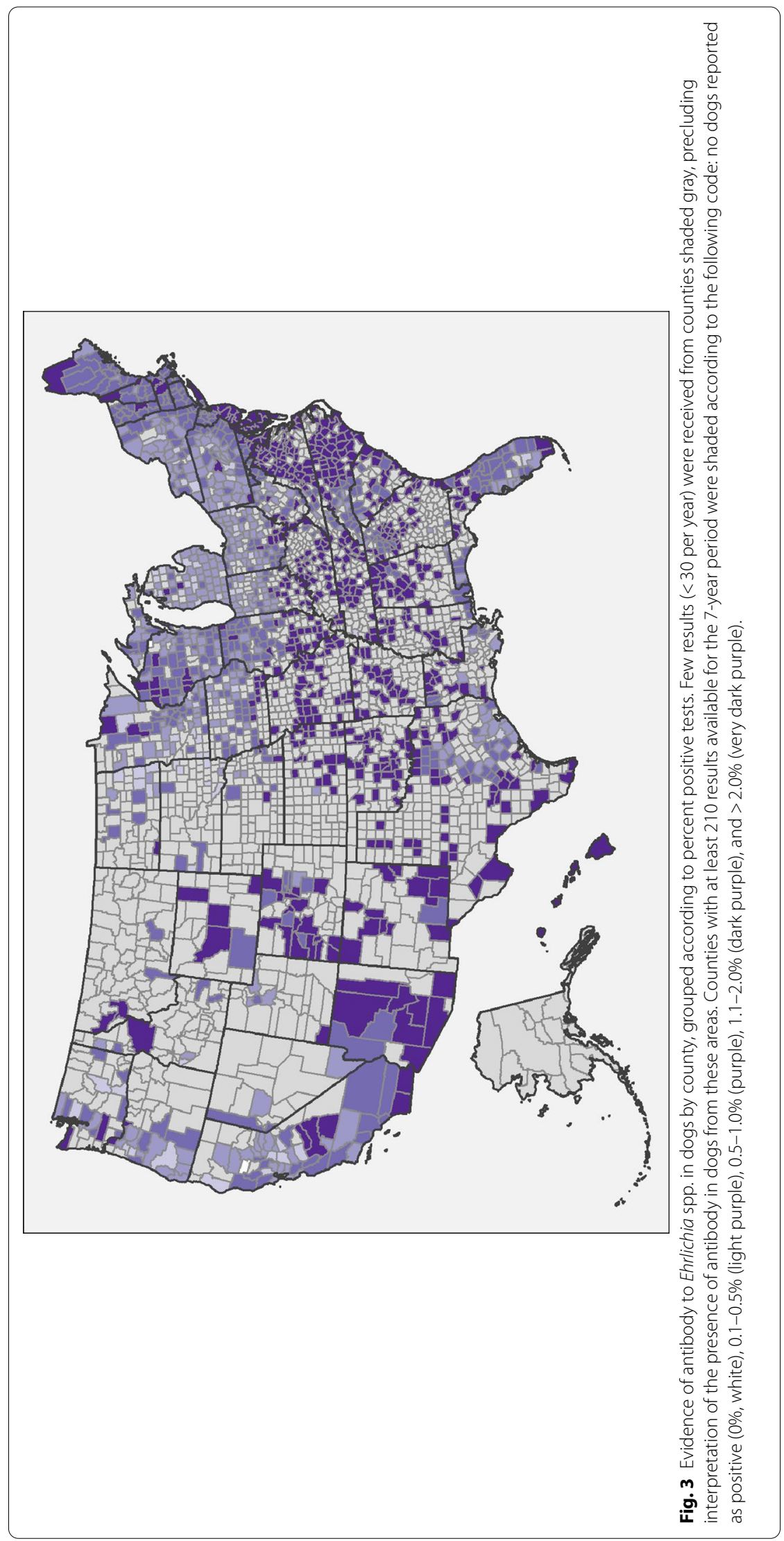




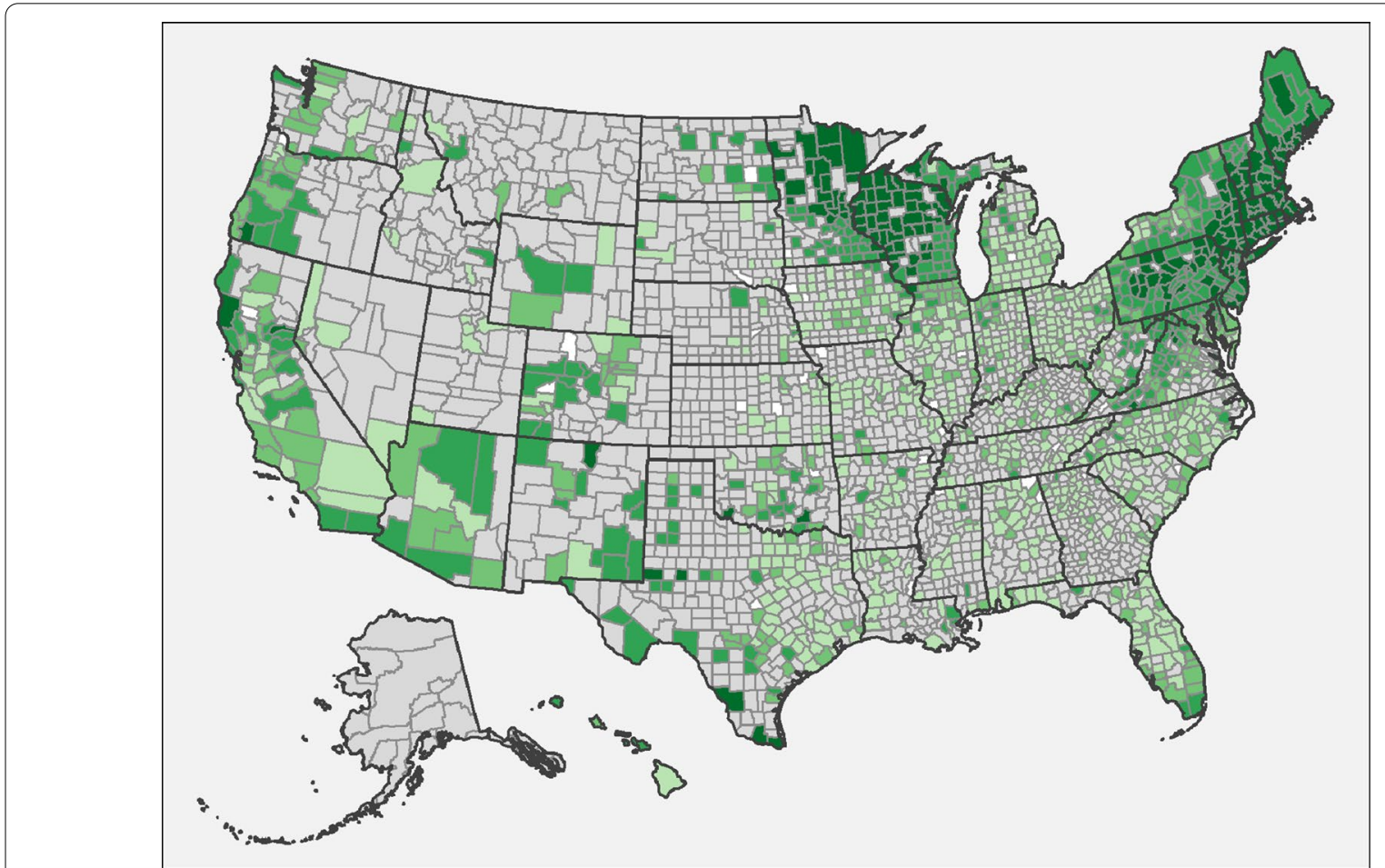

Fig. 4. Evidence of antibody to Anaplasma spp. in dogs by county, grouped according to percent positive tests. Few results ( $<30$ per year) were received from counties shaded gray, precluding interpretation of the presence of antibody in dogs from these areas. Counties with at least 210 results available for the 7-year period were shaded according to the following code: no dogs reported as positive (0\%, white), $0.1-0.5 \%$ (light green), $0.5-1.0 \%$ (green), $1.1-5.0 \%$ (dark green), and $>5.0 \%$ (very dark green)

decreases in Lyme-endemic areas, while increases in B. burgdorferi were observed in non-endemic geographies, suggesting continued spread of this infection into new areas. Finally, the data show a positive association between seroprevalence of vector-borne disease agents in dogs and reported human cases of disease. Regular screening of canine pets can not only improve healthy outcomes for dogs but can also provide insight into the risk of vector-borne disease for people.

\section{Abbreviation}

ELISA: Enzyme-linked immunosorbent assay.

\section{Acknowledgements}

We are grateful to the thousands of veterinary clinics throughout the US who continue to monitor the health of their patients by testing dogs for vectorborne disease agents. The veterinary profession's dedication to the health of their patients and their communities is commendable. Funding to support analysis of data was provided by the Krull-Ewing Endowment at Oklahoma State University. Outstanding scientific and technical support was provided by a number of individuals at IDEXX Laboratories, Inc. (Ramaswamy Chandrashekar and Keith Potts) and Oklahoma State University (Rachel Beam, Brit
Johnson, Skyla Johnston, and Kellee Sundstrom), who assisted in validating and assembling the data for analysis.

\section{Authors' contributions}

All authors participated in the design and implementation of the study and all revised the final version of the manuscript. All authors read and approved the final manuscript.

\section{Funding}

Direct funding for data summary and analysis was provided by IDEXX Laboratories, Inc., and the Krull-Ewing Endowment at Oklahoma State University.

\section{Availability of data and materials}

Data from this study are available for review on reasonable request to IDEXX Laboratories, Inc.

\section{Ethics approval and consent to participate}

No animals were treated or handled in this study and no ethical approval was required. All test results were provided anonymously.

\section{Consent for publication}

Not applicable.

\section{Competing interests}

$\mathrm{JBr}, \mathrm{JBu}, \mathrm{AK}$, and $\mathrm{MB}$ are employees of IDEXX. SL has received honoraria, expense reimbursement, and research support from several companies that 
manufacture parasite control and diagnostic products. JP and BD have no competing interests to declare.

\section{Author details}

${ }^{1}$ Department of Veterinary Pathobiology, College of Veterinary Medicine, Oklahoma State University, Stillwater, OK, USA. ${ }^{2}$ IDEXX Laboratories, Inc., Westbrook, ME, USA.

Received: 14 October 2020 Accepted: 1 December 2020

Published online: 06 January 2021

\section{References}

1. Bowman D, Little SE, Lorentzen L, Shields J, Sullivan MP, Carlin EP. Prevalence and geographic distribution of Dirofilaria immitis, Borrelia burgdorferi, Ehrlichia canis, and Anaplasma phagocytophilum in dogs in the United States: results of a national clinic-based serologic survey. Vet Parasitol. 2009;160:138-48.

2. Little SE, Beall MJ, Bowman DD, Chandrashekar R, Stamaris J. Canine infection with Dirofilaria immitis, Borrelia burgdorferi, Anaplasma spp., and Ehrlichia spp. in the United States, 2010-2012. Parasites Vectors. 2014;7:257.

3. Creevy KE, Grady J, Little SE, Moore GE, Strickler BG, Thompson S, Webb JA. 2019 AAHA canine life stage guidelines. J Am Anim Hosp Assoc. 2019;55:267-90.

4. Little SE, Heise SR, Blagburn BL, Callister SM, Mead PS. Lyme borreliosis in dogs and people in the USA. Trends Parasitol. 2010;26:213-8.

5. Nicholson WL, Allen KE, McQuiston JH, Breitschwerdt EB, Little SE. The increasing recognition of rickettsial pathogens in dogs and people. Trends Parasitol. 2010;26:205-12.

6. Beall MJ, Alleman AR, Breitschwerdt EB, Cohn LA, Couto CG, Dryden MW, Guptill LC, lazbik C, Kania SA, Lathan P, Little SE, Roy A, Sayler KA, Stillman BA, Welles EG, Wolfson W, Yabsley MJ. Seroprevalence of Ehrlichia canis, Ehrlichia chaffeensis and Ehrlichia ewingii in dogs in North America. Parasites Vectors. 2012;5:29.

7. Herrin BH, Peregrine AS, Goring J, Beall MJ, Little SE. Canine infection with Borrelia burgdorferi, Dirofilaria immitis, Anaplasma spp. and Ehrlichia spp. in Canada, 2013-2014. Parasites Vectors. 2017;10:244.

8. Watson SC, Liu Y, Lund RB. A Bayesian spatio-temporal model for forecasting the prevalence of antibodies to Borrelia burgdorferi, causative agent of Lyme disease, in domestic dogs within the contiguous United States. PLoS ONE. 2017;12:e0174428.

9. Saleh MN, Sundstrom KD, Duncan KT, lentile MM, Jordy J, Ghosh P, Little SE. Show us your ticks: a survey of ticks infesting dogs and cats across the USA. Parasites Vectors. 2019:12:595.

10. Dewage BG, Little S, Payton M, Beall M, Braff J, Szlosek D, Buch J, Knupp A. Trends in canine seroprevalence to Borrelia burgdorferi and Anaplasma spp. in the eastern USA, 2010-2017. Parasites Vectors. 2019:12:476.

11. Drake J, Wiseman S. Increasing incidence of Dirofilaria immitis in dogs in USA with focus on the southeast region 2013-2016. Parasites Vectors. 2018;11:39.

12. Drake J, Parrish RS. Dog importation and changes in heartworm prevalence in Colorado 2013-2017. Parasites Vectors. 2019;12:207.

13. Herrin BH, Zajac AM, Little SE. Confirmation of Borrelia burgdorferi sensu stricto and Anaplasma phagocytophilum in Ixodes scapularis, southwestern Virginia. Vector Borne Zoonotic Dis. 2014;14:821-3.

14. Clow KM, Leighton PA, Ogden NH, Lindsay LR, Michel P, Pearl DL, Jardine CM. Northward range expansion of Ixodes scapularis evident over a short timescale in Ontario, Canada. PLoS ONE. 2017;12:e0189393.

15. Sonenshine DE. Range expansion of tick disease vectors in North America: implications for spread of tick-borne disease. Int J Environ Res Public Health. 2018;15:478.

16. Hahn MB, Eisen L, McAllister J, Savage HM, Mutebi JP, Eisen RJ. Updated reported distribution of Aedes (Stegomyia) aegypti and Aedes (Stegomyia) albopictus (Diptera: Culicidae) in the United States, 1995-2016. J Med Entomol. 2017:54:1420-4.
17. Herrin BH, Beall MJ, Feng X, Papeş M, Little SE. Canine and human infection with Borrelia burgdorferi in the New York City metropolitan area. Parasites Vectors. 2018;11:187.

18. Rosenberg R, Lindsey NP, Fischer M, Gregory CJ, Hinckley AF, Mead PS, Paz-Bailey G, Waterman SH, Drexler NA, Kersh GJ, Hooks H, Partridge SK, Visser SN, Beard CB, Petersen LR. Vital signs: trends in reported vectorborne disease cases_-United States and Territories, 2004-2016. MMWR Morb Mortal Wkly Rep. 2018;67:496-501.

19. Stillman BA, Monn M, Liu J, Thatcher B, Foster P, Andrews B, Little S, Eberts M, Breitschwerdt EB, Beall MJ, Chandrashekar R. Performance of a commercially available in-clinic ELISA for detection of antibodies against Anaplasma phagocytophilum, Anaplasma platys, Borrelia burgdorferi, Ehrlichia canis, and Ehrlichia ewingii and Dirofilaria immitis antigen in dogs. J Am Vet Med Assoc. 2014;245:80-6.

20. Blagburn BL, Lindsay DS, Vaughn JK, Rippey NS, Wright JC, Lynn RC, Kelch WJ, Ritchie GC, Hepler DI. Prevalence of canine parasites based on fecal flotation. Compend Contin Educ Pract Vet. 1996;18:483-509.

21. R Core Team. R: a language and environment for statistical computing. R Foundation for Statistical Computing, Vienna, Austria. 2019. https:// www.R-project.org/.

22. Rudis B. Albersusa: tools, shapefiles and data to work with an 'AlbersUSA' composite projection. R package version 0.4.1. https://github.com/hrbrm str/albersusa. Accessed 1 July 2020.

23. Tennekes M. Tmap: thematic maps in R. J Stat Softw. 2018;84:1-39.

24. Centers for Disease Control and Prevention (CDC). http://www.cdc.gov/ mmwr/mmwr_nd/. Accessed 1 July 2020.

25. United States Census Bureau. 2017. http://www.census.gov/popest/data/ intercensal/index.html. Accessed 1 July 2020.

26. American Veterinary Medical Association Pet Ownership and Demographic Sourcebook, 2017-2018 Edition. https://www.avma.org/sites /default/files/resources/AVMA-Pet-Demographics-Executive-Summa ry.pdf. Accessed 21 Sept 2020.

27. Self SW, Pulaski CN, McMahan CS, Brown DA, Yabsley MJ, Gettings JR. Regional and local temporal trends in the prevalence of canine heartworm infection in the contiguous United States: 2012-2018. Parasites Vectors. 2019:12:380.

28. American Heartworm Society. No state is heartworm free. AHS Press Release 2020. https://www.heartwormsociety.org/veterinary-resources/ incidence-maps. Accessed 15 Sept 2020.

29. Companion Animal Parasite Council. Understanding the maps-key factors that influence the results. CAPC 2020. https://capcvet.org/artic les/understanding-the-maps-key-factors-that-influence-the-results/. Accessed 15 Sept 2020

30. Hays KM, Rodriguez JY, Little SE, Litster AL, Mwacalimba KK, Sundstrom KD, Amodie DM, Serrano MA, Guerios SD, Lane JN, Levy JK. Heartworm prevalence in dogs versus cats: multiple diagnostic modalities provide new insights. Vet Parasitol X. 2020;4:100027.

31. Levine JF, Apperson CS, Levin M, Kelly TR, Kakumanu ML, Ponnusamy L, Sutton H, Salger SA, Caldwell JM, Szempruch AJ. Stable transmission of Borrelia burgdorferi sensu stricto on the outer banks of North Carolina. Zoonoses Public Health. 2017;64:337-54.

32. Littman MP, Gerber B, Goldstein RE, Labato MA, Lappin MR, Moore GE. ACVIM consensus update on Lyme borreliosis in dogs and cats. J Vet Intern Med. 2018;32:887-903.

33. Eisen RJ, Eisen L. The blacklegged tick, Ixodes scapularis: an increasing public health concern. Trends Parasitol. 2018;34:295-309.

34. Norris SJ, Barbour AG, Fish D, Diuk-Wasser MA. Response to Esteve-Gassent et al.: flaB sequences obtained from Texas PCR products are identical to the positive control strain Borrelia burgdorferi B31. Parasites Vectors 2015:8:310.

35. Adetunji SA, Krecek RC, Castellanos G, Morrill JC, Blue-McLendon A, Cook WE, Esteve-Gassent MD. Seroprevalence of Borrelia burgdorferi antibodies in white-tailed deer from Texas. Int J Parasitol Parasites Wildl. 2016:5:168-74.

36. Springer YP, Eisen L, Beati L, James AM, Eisen RJ. Spatial distribution of counties in the continental United States with records of occurrence of Amblyomma americanum (Ixodida: Ixodidae). J Med Entomol. 2014;51:342-51. 
37. Pritt BS, Allerdice MEJ, Sloan LM, Paddock CD, Munderloh UG, Rikihisa Y, Tajima T, Paskewitz SM, Neitzel DF, Hoang Johnson DK, Schiffman E, Davis JP, Goldsmith CS, Nelson CM, Karpathy SE. Proposal to reclassify Ehrlichia muris as Ehrlichia muris subsp. muris subsp. nov. and description of Ehrlichia muris subsp. eauclairensis subsp. nov., a newly recognized tick-borne pathogen of humans. Int J Syst Evol Microbiol. 2017;67:2121-6.

38. Hegarty BC, Maggi RG, Koskinen P, Beall MJ, Eberts M, Chandrashekar R, Breitschwerdt EB. Ehrlichia muris infection in a dog from Minnesota. J Vet Intern Med. 2012;26:1217-20.

39. Lee X, Coyle DR, Johnson DK, Murphy MW, McGeehin MA, Murphy RJ, Raffa KF, Paskewitz SM. Prevalence of Borrelia burgdorferi and Anaplasma phagocytophilum in Ixodes scapularis (Acari: Ixodidae) nymphs collected in managed red pine forests in Wisconsin. J Med Entomol. 2014;51:694-701.

40. Prusinski MA, Kokas JE, Hukey KT, Kogut SJ, Lee J, Backenson PB. Prevalence of Borrelia burgdorferi (Spirochaetales: Spirochaetaceae), Anaplasma phagocytophilum (Rickettsiales: Anaplasmataceae), and Babesia microti (Piroplasmida: Babesiidae) in Ixodes scapularis (Acari: Ixodidae) collected from recreational lands in the Hudson Valley Region, New York State. J Med Entomol. 2014:51:226-36.

41. Tokarz R, Tagliafierro T, Sameroff S, Cucura DM, Oleynik A, Che X, Jain K, Lipkin WI. Microbiome analysis of Ixodes scapularis ticks from New York and Connecticut. Ticks Tick Borne Dis. 2019;10:894-900.

42. Ghosh P, Saleh MN, Sundstrom K, lentile M, Little SE. Ixodes spp. from dogs and cats in the United States: diversity, seasonality, and prevalence of Borrelia burgdorferi and Anaplasma phagocytophilum. Vector Borne Zoonotic Dis. 2020. https://doi.org/10.1089/vbz.2020.2637.

43. Dantas-Torres F. Biology and ecology of the brown dog tick, Rhipicephalus sanguineus. Parasites Vectors. 2010;3:26.

44. Jones EO, Gruntmeir JM, Hamer SA, Little SE. Temperate and tropical lineages of brown dog ticks in North America. Vet Parasitol Reg Stud Rep. 2017;7:58-61.
45. Krämer F, Hüsken R, Krüdewagen EM, Deuster K, Blagburn B, Straubinger RK, Butler J, Fingerle V, Charles S, Settje T, Schunack B, Stanneck D. Prevention of transmission of Borrelia burgdorferi sensu lato and Anaplasma phagocytophilum by Ixodes spp. ticks to dogs treated with the Seresto ${ }^{\circledR}$ collar (imidacloprid 10\% + flumethrin 4.5\%). Parasitol Res. 2020;119:299-315.

46. Honsberger NA, Six RH, Heinz TJ, Weber A, Mahabir SP, Berg TC. Efficacy of sarolaner in the prevention of Borrelia burgdorferi and Anaplasma phagocytophilum transmission from infected Ixodes scapularis to dogs. Vet Parasitol. 2016;222:67-72.

47. Baker CF, McCall JW, McCall SD, Drag MD, Mitchell EB, Chester ST, Larsen D. Ability of an oral formulation of afoxolaner to protect dogs from Borrelia burgdorferi infection transmitted by wild Ixodes scapularis ticks. Comp Immunol Microbiol Infect Dis. 2016;49:65-9.

48. Millen K, Kugeler KJ, Hinckley AF, Lawaczeck EW, Mead PS. Elevated Lyme disease seroprevalence among dogs in a nonendemic county: harbinger or artifact? Vector Borne Zoonotic Dis. 2013;13:340-1.

49. Duncan AW, Correa MT, Levine JF, Breitschwerdt EB. The dog as a sentinel for human infection: prevalence of Borrelia burgdorferi C6 antibodies in dogs from southeastern and mid-Atlantic states. Vector Borne Zoonotic Dis. 2004;4:221-9.

50. Mead P, Goel R, Kugeler K. Canine serology as adjunct to human Lyme disease surveillance. Emerg Infect Dis. 2011;17:1710-2.

\section{Publisher's Note}

Springer Nature remains neutral with regard to jurisdictional claims in published maps and institutional affiliations.
Ready to submit your research? Choose BMC and benefit from:

- fast, convenient online submission

- thorough peer review by experienced researchers in your field

- rapid publication on acceptance

- support for research data, including large and complex data types

- gold Open Access which fosters wider collaboration and increased citations

- maximum visibility for your research: over $100 \mathrm{M}$ website views per year

At BMC, research is always in progress.

Learn more biomedcentral.com/submissions 